\title{
Study of safety indicators of salted Bracken Fern Pteridium Aquilinum (L.) Kuhn harvested in the Krasnoyarsk Krai
}

\author{
Daria Cheremnykh ${ }^{1, *}$, Galina Gubanenko ${ }^{1}$, Ekaterina Rechkina ${ }^{2}$, Tatiana Balyabina ${ }^{1}$, and \\ Olga Kiseleva ${ }^{3}$ \\ ${ }^{1}$ Siberian Federal University, Svobodny prospect, 79, 660041 Krasnoyarsk, Russia \\ ${ }^{2}$ Krasnoyarsk State Agrarian University, Mira Avenue, 90, 660049 Krasnoyarsk, Russia \\ ${ }^{3}$ Siberian State University of Science and Technology named after M.F. Reshetnev, Mira Avenue, 82, \\ 660049 Krasnoyarsk, Russia
}

\begin{abstract}
The article first defined the hygienic safety indicators of salted Bracken Fern Pteridium Aquilinum (L.) Kuhn harvested in the Krasnoyarsk region and carried out a comparative analysis with the regulated safety indicators of salted vegetables and mushrooms established in the territory of the EAEU Customs Union. The harvesting and processing of Bracken Fern was assessed.
\end{abstract}

\section{Introduction}

Safe and quality food is a key requirement of today's market, both for the consumer and the producer. The consumer has begun to pay close attention to the quality and safety of food products, and the manufacturer must be clearly aware of its responsibility and maintain its reputation. The spirit of the new trends for a proper and healthy diet requires special vigilance with regard to the production of food, and scientists have the task of studying and researching the physical and chemical quality and safety indicators of raw materials used for the production of healthy products.

Literature provides a significant amount of information on the use of various plant raw materials, including the use of wild herbs, plants and berries, as a source of biologically active substances (BAS) [1-5]. Krasnoyarsk Krai is rich in food forest resources, has the potential to harvest wild-growing crops and provide the domestic and foreign consumer market with products of their processing. One of the poorly studied and promising for industrial processing is Bracken Fern which grows in the Krasnoyarsk Krai.

Common Bracken Fern (Pteridium aquilinum L. Kuhn.) - a perennial plant belonging to the spore genus of the vascular division, reaching a height of $150 \mathrm{~cm}$, distributed virtually throughout Russia, up to the polar northern latitudes. Habitat includes deciduous and coniferous forests, shrub thickets, upland open terrain, and forest edge in pine, light and poor ground cover. Bracken Fern is a food plant until the beginning of leaf formation (vaia), when the height of the shoot from the soil is no more than $50-60 \mathrm{~cm} \mathrm{[6].}$

\footnotetext{
${ }^{*}$ Corresponding author: darya.cheremnykh.94@mail.ru
} 
Bracken Fern (Pteridium aquilinum L. Kuhn.) can serve as a source of BAS in the production of new foods. Data on the presence of protein substances are consistent between the authors [7, 8] and their content in young fern shoots reaches up to $31 \mathrm{~g}$ per $100 \mathrm{~g}$ of dry weight. Common Bracken Fern (Pteridium aquilinum L. Kuhn.) contains 15 amino acids, of which 6 are essential [7], and the work [9] noted the presence of 17 amino acids with the calculation of the chemical scor, which indicates a single limiting amino acid methionine + cystine. Thus, the content of amino acids in the proteins of Pteridium aquilinum (L.) Kuhn for most essential amino acids exceeds their content in the reference protein.

In the literature, data on the carbohydrate composition are represented by fiber from 0.9 $\mathrm{g}$ to $1.7 \mathrm{~g}[7,9]$, starch from $0.18 \mathrm{~g}$ to $3 \mathrm{~g}[7,8]$, pectin up to $7 \mathrm{~g}$ [8], also the authors [9] note the presence of lignin, and in [8] presented a clear content of up to $11.71 \mathrm{~g}$. The study of the chemical composition provided data on the content of glucose - $12.26 \mathrm{~g}$; fructose $-5.76 \mathrm{~g}$; sucrose $-0.49 \%$ and ribose $-0.22 \mathrm{~g}$ [8].

The authors [9] also pointed out the presence of traces of organic acids in Bracken Fern, such as apple acid, citric acid, aconite acid, caffeic acid, protocachetic acid, and shikimic acid. Shalisko I. V. together with his co-authors [10] presented data on the content of fatty acids in frozen Bracken Fern - linoleic $(26.02 \%)$, palmitic (24.86\%), arachidonic $(14.83 \%)$, $\alpha$-linolenic (11.88\%), oleic (4.71\%), $\gamma$-linolenic (3.13\%), hexadecatrienoic (2.33\%), digomo$\gamma$-linolenic $(2.28 \%)$, stearic $(1.06 \%)$, thymidonic $(0.92 \%)$, begonic $(0.96 \%)$ and arachidonic $(0.78 \%)$.

The vitamin component is represented by Vitamin A $181 \mathrm{mcg}$; Vitamin C $26.6 \mathrm{mg}$; Vitamin E $2.67 \mathrm{mg}$; B-carotene $2.04 \mathrm{mg}$, Vitamin PP $4.98 \mathrm{mg}$, and their quantitative content does not vary greatly among the authors $[7,9]$. But the mineral composition presented in the works $[7,8,9]$ has some differences and the content of $\mathrm{K}$ is in the range of 310 to $370 \mathrm{mg}$; $\mathrm{Ca}$ - 110 to $140 \mathrm{mg}$; $\mathrm{Na}$ - 49 to $140 \mathrm{mg}$; P - 75 to $101 \mathrm{mg}$; $\mathrm{S}-100 \mathrm{mg}$; $\mathrm{Mg}-14 \mathrm{mg}$; $\mathrm{Cu}-6.80$ $\mathrm{mg}$; $\mathrm{Ni}-2.40 \mathrm{mg}$ and $\mathrm{Mn}-0.60 \mathrm{mg}$.

In the work [11], the authors Fedko I.V., Kitapova R.R. and others presented the results of a comparative study of the content of macro- and microelements in ferns Pansy, Straus and Common Eagle growing in Western Siberia. During the study, the authors divided the chemical elements into 3 groups: I (biogenic elements - K, Ca, Co, Fe, Na, Zn); II (with toxic effect on plant organism - Ag, Ba, Br, Cr, Sr); III (toxicants - As, Sb, Th, U). The results of the analysis showed that all samples contain elements of all three groups. However, in terms of the content of elements of group I Bracken Fern is significantly inferior to ostrich, in particular $\mathrm{Ca} 3.120 \%$ and $7.760 \%$ and $\mathrm{Na} 0.045 \%$ and $0.135 \%$.

Consumer properties of a food product include organoleptic, physico-chemical parameters, nutritional value and safety. According to the literature and regulatory documentation, there are different safety indicators determining the toxicity of fresh and processed ferns. For example, the works of foreign authors [12-15] present studies on the toxic effects of Pteridium aquilinum L. Kuhn associated with the content of ptacquiloside (PTA), which is a norsesquiterpene glucoside. It was found that this carcinogen can increase the risk of cancer in cattle and sheep consuming fresh shoots of Pteridium aquilinum L. Kuhn and thus can be transmitted to humans through milk or meat of these animals. Another potential route of transmission of the fern carcinogen to humans, PTA can leach from the plant into water resources or be dispersed through the air during plant respiration due to spores. The authors quantified using HPLC and found that PTA is unstable and rapidly undergoes aromatization with deglucosylation of D-(+)-glucose to form pterosin B (PTB), a non-carcinogenic compound, under acidic or alkaline aqueous conditions, and even in hot water.

Domestic authors I. E. Tsapalova, M.D. Gubina, O.V. Golub and V. M. Pozniakovsky [5] studied 3 toxic elements, presented in Table 1, as safety indicators of fresh Bracken Fern. 
Table 1. Content of toxic elements in the fern Pteridium aquilinum L. Kuhn

\begin{tabular}{|c|c|}
\hline Indicator & Content, $\mathbf{~ g} / \mathbf{k g}$ \\
\hline Lead & 0.5 \\
\hline Zinc & 0.2 \\
\hline Copper & 0.03 \\
\hline
\end{tabular}

Thus, domestic and foreign authors investigate various indicators that determine, in their opinion, the safety of the fern. F we refer to the regulatory sources that regulate the safety indicators of the TR TS $021 / 2011$ "On the safety of food products", fern as a type of plant raw materials is absent in this document. Section 1.4 "fruit and vegetable products" presents safety indicators for vegetables, mushrooms and their products. To determine the safety indicators it is necessary to assign the fern to a particular commodity group of vegetables or mushrooms.

On this issue in the literature and regulatory sources present different points of view. For example, in the textbook "Examination of wild fruits, berries and herbaceous plants. Quality and Safety" [5] gave a classification of herbaceous plants, presented in Figure 1. The authors identified the fern in the group of vegetable plants according to the classification features. In accordance with the requirements of the normative document GOST ISO 3493-2017 Interstate Standard "Spices. Vanilla" in Note 1, ferns and mushrooms are referred to "spore plants", which gives grounds to attribute the fern to the group of fungi.

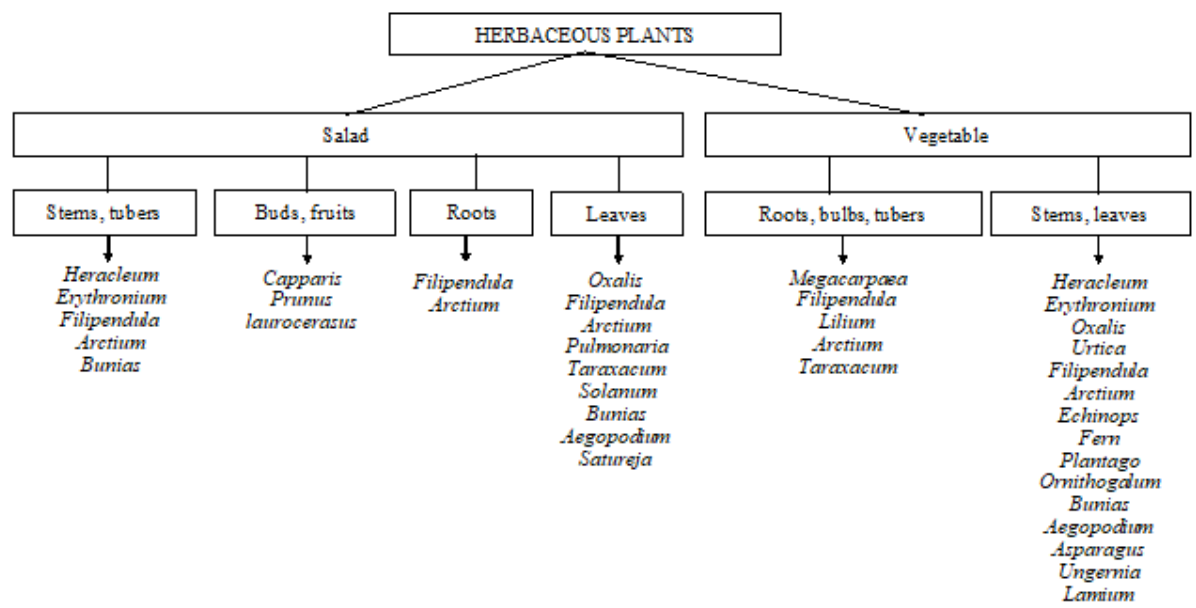

Fig. 1. Classification of herbaceous food plants

Studying the current technical documents for fern processing products TU 9167-0014601110656-2013, TU 9167-125-79036538-2013 "Salted ferns", TU 9161-003-017269862005 "Canned and semi-preserved salted ferns", TU 9161-083 -44388488-2005 "Fern preserves", TU 9161-018-48848231-2004 "Canned fern", TU 9769-012-01726621-2002 "Salted Bracken Fern" developers choose according to the classifier of state standards (KGS), group N52: Pickled berries, fruits, vegetables and mushrooms.

Thus, the analysis of literary and regulatory sources does not allow us to uniquely identify which product group refers to a fern and, accordingly, to establish a list of regulated indicators of safety for fresh and processed Bracken Fern. Currently, Bracken Fern in the food industry, in public catering and for sale to the consumer through the trade is used in salted form. In this regard, we analyzed the safety indicators of salted vegetables and mushrooms in the current interstate regulations of the TR TS 021/2011 "On the safety of food products" (Table 2). 
Table 2. Safety indicators of salted vegetables and mushrooms according to TR TS $021 / 2011$

\begin{tabular}{|c|c|c|}
\hline & Salted vegetables & Salted mushrooms \\
\hline Microbiological safety standards (pathogenic) & 25 \\
\hline \multicolumn{2}{|c|}{ Indicator } & Weight of the product (g) in which it is not allowed \\
\hline $\begin{array}{c}\text { Pathogens, including } \\
\text { salmonellae }\end{array}$ & 25 & 0.1 \\
\hline $\begin{array}{c}\text { Mesophilic sulfate- } \\
\text { reducing clostridia }\end{array}$ & - & 0.5 \\
\hline Hygienic safety requirements & \multicolumn{2}{|c|}{} \\
\hline \multicolumn{2}{|c|}{ Indicator } & Permissible levels, mg/kg, no more \\
\hline Lead & 0.5 & 0.5 \\
\hline Arsenic & 0.2 & 0.1 \\
\hline Cadmium & 0.03 & 0.5 \\
\hline Mercury & 0.02 & 0.1 \\
\hline HCH $(\alpha, \beta, \gamma$ isomers) & 0.5 & 0.1 \\
\hline DDT and its metabolites & &
\end{tabular}

According to Table 2, the list of regulated safety indicators is different. For salted mushrooms by microbiological indicators of safety it is necessary to determine mesophilic sulfate-reducing clostridia and by hygienic indicators allowable levels of toxic elements are higher in comparison with vegetables, while the regulatory values of lead and pesticides are the same.

Thus, fern Pteridium aquilinum L. Kuhn is characterized by high nutritional value due to the content of BAS, organoleptic indicators, which determines its demand in the domestic and foreign consumer markets. However, fern can contain in its chemical composition poisonous glycosides and toxic elements that determine the danger to the human body. In this regard, the assessment of the processing potential of Bracken Fern in the Krasnoyarsk Krai and the study of safety indicators of its product processing has practical relevance and is an important topic for research

\section{Methods and objects}

The research objects used were: Sample 1 - salted fern harvested at Dubenskoye; Sample 2 salted fern harvested at Kuragino; Sample 3 - salted fern harvested at Dzerzhinskoye; Sample 4 - salted fern harvested at Ermakovskoye; Sample 5 - salted fern harvested at Shushenskoye; Sample 6 - salted fern harvested at Kozulka.

Research Methods. Determination of toxic elements: lead according to GOST 26932, GOST 30178, GOST 30538; arsenic - according to GOST 26930, GOST 30538, GOST 31628; cadmium - according to GOST 26933, GOST 30178, GOST 30538; mercury according to GOST 26927; $\mathrm{HCH}(\alpha, \beta, \gamma$ isomers) - MU 4120.

\section{Discussion of results}

In the Krasnoyarsk Krai OOO "Procurement and Production Complex of the Consumers Union" carries out economic activities on the harvesting and processing of Bracken Fern, the dynamics of harvesting is shown in Figure 2. Bracken Fern is collected in 6 districts, including the northeastern direction of Krasnoyarsk - Dzerzhinskoye; the southeastern Sayan Mountains - Dubenskoye, Shushenskoye, Ermakovskoye; the highlands of the eastern Sayan - Kuragino and the lowlands of the eastern Sayan - Kozulka. From 2012 to 2020, the average 
harvest and processing volume is about 687 tons of fresh fern per season - May, June, and July.

\section{Fern}

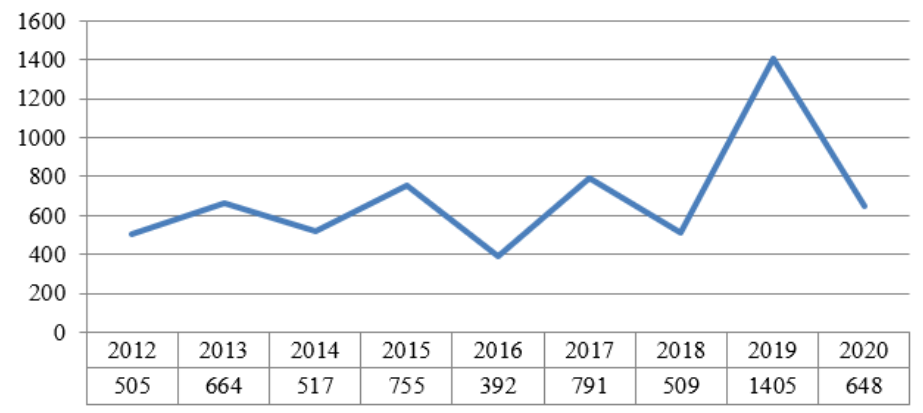

Fig. 2. Dynamics of fern harvesting of Krasnoyarsk Krai Krai Consumers Union

Salted Bracken Fern harvested by Krasnoyarsk Krai Consumer Union is successfully sold on the Russian market, but more is exported to the Asian market, which accounts for about $70 \%$ of the total processed volume. According to Figure 1, from 2012 to 2018, harvest volumes range from 400 to 800 tons per season, with 2019 characterized by the highest yields and processing capacity. In 2020, harvest decreased by 54\% compared to 2019 due to restrictive measures during the COVID-2019 pandemic, which negatively impacted processing volumes and sales of salted ferns in the foreign market.

Currently, in the Krasnoyarsk Krai, only salted fern is obtained from fresh ferns. In this regard, we investigated the potential hygienic indicators of salted fern in 6 districts of Krasnoyarsk Krai and carried out a comparative analysis with the safety indicators of salted vegetables and mushrooms (Table 3).

Table 3. Results of comparative analysis of safety indicators of pickled vegetables, mushrooms and Bracken fern

\begin{tabular}{|c|c|c|c|c|c|c|c|c|}
\hline \multirow[t]{2}{*}{ Indicators } & \multicolumn{2}{|c|}{ TR TS 021/2011 } & \multirow{2}{*}{$\begin{array}{c}\text { Sample } \\
1\end{array}$} & \multirow{2}{*}{$\begin{array}{c}\text { Sample } \\
2\end{array}$} & \multirow{2}{*}{$\begin{array}{c}\text { Sample } \\
3\end{array}$} & \multirow{2}{*}{$\begin{array}{c}\text { Sample } \\
4\end{array}$} & \multirow{2}{*}{$\begin{array}{c}\text { Sample } \\
5\end{array}$} & \multirow{2}{*}{$\begin{array}{c}\text { Sample } \\
6\end{array}$} \\
\hline & $\begin{array}{c}\text { Salted } \\
\text { vegetables }\end{array}$ & $\begin{array}{c}\text { Salted } \\
\text { mushrooms }\end{array}$ & & & & & & \\
\hline Lead & 0.5 & 0.5 & 0.08 & 0.07 & 0.05 & 0.05 & 0.2 & 0.1 \\
\hline Arsenic & 0.2 & 0.5 & 0.003 & 0.001 & 0.002 & 0.001 & 0.005 & 0.006 \\
\hline Cadmium & 0.03 & 0.1 & 0.001 & 0.001 & 0.01 & 0.009 & 0.007 & 0.01 \\
\hline Mercury & 0.02 & 0.05 & 0.001 & 0.004 & 0.002 & 0.0022 & 0.005 & 0.002 \\
\hline $\begin{array}{l}\mathrm{HCH}(\alpha, \beta, \\
\gamma \text { isomers })\end{array}$ & 0.5 & 0.5 & 0.01 & 0.01 & 0.009 & 0.001 & 0.009 & 0.06 \\
\hline $\begin{array}{l}\text { DDT and } \\
\text { its } \\
\text { metabolites }\end{array}$ & 0.1 & 0.1 & 0.001 & 0.001 & 0.001 & 0.002 & 0.001 & 0.003 \\
\hline
\end{tabular}

A comparative analysis of the potential safety indicators of the Bracken Fern, with the regulated indicators of salted vegetables and mushrooms, indicates that the standard values of the indicators of the studied samples do not exceed the permissible level.

Thus, the results of the analysis of the volumes of harvesting and processing of Common fern in the Krasnoyarsk Krai suggest the conclusion about the significant resource potential in the region and the limited method of processing - salting, which restrains the possibility of new food products on its basis. The results of the study of hygienic indicators of salted fern and their comparison with the regulated indicators of salted vegetables and mushrooms give grounds to assert that the product of fern processing meets the established safety requirements and can be used without restrictions for food purposes. 


\section{References}

1. N. E. Posokina, N. M. Alabina, A. Yu. Davydova, Agrarnaya nauka, 11-12, 134 (2020)

2. E. M. Serba, G. S. Volkova, E. N. Sokolova, N.A. Fursova, T. V. Yuraskina, Storage and Processing of Agricultural Raw Materials, 4, 45 (2018)

3. Yu. A. Prokopchenko, M.A. Ershov, Modern ecological, biological and chemical research, technology and production technology, 213 (2018)

4. Z. N. Khatko, T. B. Kolotiy, I. S. Polyakova, New Technologies, 1, 87 (2020)

5. D. V. Kupchak, A. A. Sinyayeva, Bulletin of Siberian University of Consumer Cooperation, 1, 35 (2020)

6. O. A. Ryazanova, M. A. Nikolaeva, Yu. N. Kleshchevsky, Food Commodity Conductor, 1, 26 (2021)

7. M. V. Centroev, B. A. Dzhamaldinova, I. U. Ushaeva, Sh. I. Idilova, Horizons of Science: Material Science and Metallurgy, 167 (2019)

8. E. V. Melnikova, Innovative Trends in the Development of Russian Science, 266 (2015)

9. I. E. Tsapalova, M.D. Gubina, O.V. Golub, V. M. Pozniakovsky, Expertise of wild fruits, berries and herbaceous plants. Quality and Safety (2005)

10. I. V. Shalisko, M. I. Dmitrichenko, V. V. Pelenko, S.V. Shakhov, Bulletin of Voronezh State University of Engineering Technologies, 3, 151 (2016)

11. I. V. Fedko, R. R. Kitapova, A. A. Khvashchevskaya, M. G. Kambalina, Fundamental Research, 6-5, 1193 (2013)

12. M. Shahin, B. L. Smith, A. S. Prakash, Mutation Research, 443, 69 (1999)

13. J.-W. Hao, X.-Q. Liu, N.-D. Chen, A.-1. Zhu, Journal of Food Composition and Analysis, $98(2021)$

14. D. da S. Freitas Ribeiro, K. M. Keller, B. Soto-Blanco, Toxins, 12, 288 (2020)

15. V. Kisielius, D. N.Lindqvista, M. B. Thygesenc, M. Rodamerd, H. C. B. Hansenb, L. H. Rasmussen, Journal of Chromatography, B, 1138 (2020)

16. TR TS 021/2011. Technical regulation "About safety of food products" 